\title{
PERBANDINGAN HASIL BELAJAR SISWA DENGAN MENGGUNAKAN MODEL PEMBELAJARAN KOOPERATIF TIPE STAD DAN PEMBELAJARAN KOOPERATIF TIPE NHT TERHADAP HASIL BELAJAR SISWA PADA MATA PELAJARAN MATEMATIKA KELAS VIII DI SMP NEGERI 1 GETASAN
}

\author{
Jonet Prasetyo \\ Alumni Magister Manajemen Pendidikan FKIP Universitas Kristen Satya Wacana \\ Sutriyono \\ Magister Manajemen Pendidikan FKIP Universitas Kristen Satya Wacana \\ sutriyono@staff.uksw.edu
}

\begin{abstract}
ABSTRAK
Penelitian ini merupakan jenis penelitian eksperimen dengan menggunakan desain penelitian Quasi Experimental Nonequivalent Control Group Design. Tujuan dari penelitian ini yaitu untuk mengetahui perbedaan hasil belajar siswa pada matapelajaran matematika, setelah diajar dengan menggunakan Model Pembelajaran Kooperatif tipe STAD dan Model Pembelajaran Kooperatif Tipe NHT. Populasi penelitian ini adalah siswa kelas VIII SMP Negeri 1 Getasan, dengan dua kelas eksperimen yaitu kelas VIII A yang memperoleh perlakuan berupa Pembelajaran Kooperatif Tipe STAD dan Kelas V III F yang memperoleh perlakuan berupa Pembelajaran Kooperatif Tipe NHT. Teknik pengumpulan data menggunakan instrumen tes, yang meliputi pretes dan postes. Untuk analisis data menggunakan uji beda t-test. Dari hasil penelitian menyatakan bahwa, terdapat perbedaan signifikan antara hasil belajar siswa yang diajar menggunakan Model Pembelajaran Kooperatif Tipe STAD dan Model Pembelajaran Kooperatif Tipe NHT pada mata pelajaran matematika. Nilai rata-rata hasil belajar matematika siswa yang diajar menggunakan Model Pembelajaran Kooperatif Tipe STAD lebih baik, daripada siswa yang diajar dengan menggunakan Model Pembelajaran Kooperatif Tipe NHT.
\end{abstract}

Kata Kunci: pembelajaran kooperatif Tipe STAD, pembelajaran kooperatif Tipe NHT, hasil belajar

\section{PENDAHULUAN}

Matematika merupakan ilmu universal yang mendasari perkembangan teknologi modern, serta mempunyai peran penting dalam berbagai disiplin dan memajukan daya pikir manusia. Perkembangan pesat di bidang teknologi informasi dan komunikasi dewasa ini dilandasi oleh perkembangan matematika di bidang teori bilangan, aljabar, analisis, teori peluang, dan diskrit. Untuk menguasai dan menciptakan teknologi di masa depan diperlukan penguasaan matematika yang kuat sejak dini (Dekdikbud, 2006). Untuk saat ini upaya untuk meningkatkan kemampuan akademis peserta didik pada mata pelajaran matematika sudah digunakan berbagai model pembelajaran, seperti model pembelajaran kontekstual, kooperatif, terpadu, kuantum dan model pembelajaran berbasis masalah. Akan tetapi kenyataan yang dijumpai di lapangan adalah, sebagian besar pengajaran matematika yang dilakukan oleh pengajar diberikan secara klasikal melalui model ceramah. Akibatnya siswa menjadi bosan, sehingga siswa kurang 
berminat untuk mengikuti pelajaran matematika.

Berdasarkan hasil observasi yang telah dilakukan di SMP Negeri 1 Getasan, diketahui bahwa ada beberapa siswa yang tidak selalu dapat memahami apa yang disampaikan pengajar. Kebanyakan siswa di lapangan lebih sering menghafal konsep, ketimbang memahami apa yang disampaikan pengajar di depan kelas. Hal tersebut berakibat siswa terlihat kesulitan untuk mengerjakan soal, ketika diberikan bentuk soal berbeda dari contoh soal yang disampaikan di depan kelas. Akibat dari kurang mampunya siswa dalam memahami materi yang disampaikan pengajar adalah penurunan hasil belajar atau prestasi siswa. Oleh karena hal tersebut perlu diperhatikan faktor-faktor yang mempengaruhi proses belajar siswa, agar siswa dapat memahami konsep materi yang disampaikan pengajar dalam proses pembelajaran, sehingga diperoleh prestasi atau hasil belajar siswa yang maksimal. Menurut Slameto (2003) faktor-faktor yang mempengaruhi prestasi atau hasil belajar dapat dikelompokkan dalam dua jenis, yaitu faktor internal dan faktor eksternal. Faktor internal, yaitu faktor yang ada dalam individu yang sedang belajar. Faktor internal meliputi faktor jasmaniah, psikologis, dan faktor kelelahan. Faktor eksternal, yaitu faktor dari luar individu yang terdiri dari faktor keluarga, sekolah, dan faktor masyarakat.

Menurut Pandoyo (1997) matematika merupakan mata pelajaran yang bersifat abstrak, sehingga dituntut kemampuan guru untuk dapat mengupayakan model yang tepat sesuai dengan tingkat perkembangan mental siswa. Untuk itu diperlukan model dan media pembelajaran yang dapat membantu siswa untuk mencapai kompetensi dasar dan indikator pembelajaran. Oleh karena karena itu, penulis melakukan penelitian dengan model pembelajaran lebih bervariasi, yang diharapkan dapat meningkatkan kreativitas siswa secara mandiri maupun kerjasama kelompok. Model pembelajaran yang akan digunakan dalam penelitian ini adalah model pembelajaran kooperatif tipe STAD dan NHT. Berdasarkan kedua model pembelajaran tersebut, penulis akan membandingkan hasil belajar siswa yang diajar menggunakan model pembelajaran kooperatid tipe STAD dan NHT pada mata pelajaran matematika kelas VIII di SMP Negeri 1 Getasan. Tujuan penelitian adalah untuk mendapatkan perbandingan hasil belajar siswa dengan menggunakan model pembelajaran kooperatif tipe STAD dan NHT pada mata pelajaran matematika kelas VIII di SMP Negeri 1 Getasan.

\section{TINJAUAN PUSTAKA}

\section{Pembelajaran Matematika}

Matematika merupakan salah satu jenis dari enam materi ilmu yaitu: matematika, fisika, biologi, psikologi, ilmu-ilmu sosial dan linguistik. Didasarkan pada pandangan konstruktivisme, hakikat matematika yakni anak yang belajar matematika dihadapkan pada masalah tertentu berdasarkan konstruksi pengetahuan yang diperolehnya ketika belajar, dan anak berusaha memecahkannya (Hamzah, 2007). Melalui proses belajar matematika peserta didik dapat memiliki sarana berpikir yang jelas dan logis, sehingga diharapkan peserta didik dapat memecahkan masalah dalam kehidupan sehari-hari. Pembelajaran matematika yang dilakukan di sekolah, hendaknya dapat mendorong peserta didik untuk berpikir secara kritis, kreatif, dan mempunyai kemampuan kerjasama.

Ciri utama matematika adalah penalaran deduktif yaitu kebenaran suatu konsep, atau pernyataan yang diperoleh sebagai akibat logis dari kebenaran sebelumnya. Namun demikian, dalam pembelajaran pemahaman konsep sering diawali secara induktif melalui pengalaman peristiwa nyata. Proses induktif-deduktif dapat digunakan untuk mempelajari konsep 
matematika. Selama mempelajari matematika di kelas, aplikasi hasil rumus atau sifat yang diperoleh dari penalaran deduktif maupun induktif sering ditemukan meskipun tidak secara formal hal ini disebut dengan belajar bernalar (Depdiknas, 2003). Sedangkan pembelajaran ialah proses yang diselenggarakan oleh guru untuk membelajarkan siswa dalam belajar bagaimana belajar memperoleh dan memproses pengetahuan, keterampilan, dan sikap (Dimyati dan Mudjiono, 2002). Dari beberapa uraian pendapat di atas dapat disimpulkan bahwa pembelajaran matematika adalah suatu proses yang diselenggarakan oleh pengajar untuk membelajarkan peserta didik guna memperoleh ilmu pengetahuan dan keterampilan matematika, serta berpikir secara jelas, logis, kritis, dan kreatif dalam memecahkan masalah pada kehidupan sehari-hari.

Tujuan pembelajaran matematika itu sendiri adalah terbentuknya kemampuan bernalar pada diri siswa yang tercermin melalui kemampuan berpikir kritis, logis, sistimatis dan memiliki sifat obyektif, jujur, disiplin dalam memecahkan suatu permasalahan baik dalam bidang matematika, bidang lain, maupun dalam kehidupan sehari-hari (PPPG, 2004).

\section{Pembelajaran Kooperatif}

Menurut Abdurrahman dan Bintoro batasan model pembelajaran kooperatif yaitu sebagai pembelajaran yang secara sadar dan sistematis mengembangkan interaksi yang silih asah, silih asih, dan silih asuh antar sesama siswa sebagai latihan hidup dalam masyarakat nyata (Nurhadi dan Senduk, 2003).

Abdurrahman dan Bintoro mengemukakan bahwa "kelompok belajar siswa kooperatif memiliki beberapa perbedaan dari pada kelompok tradisional". Perbedaan tersebut dapat dilihat pada Tabel 1.

Menurut Sanjaya (2008) keunggulan dan kelemahan pembelajaran kooperatif adalah sebagai berikut:

Keunggulan yaitu siswa tidak terlalu menggantungkan pada guru, akan tetapi dapat

Tabel 1. Perbedaan kelompok Kooperatif dengan Kelompok Tradisional

\begin{tabular}{|c|c|}
\hline Kelompok Kooperatif & Kelompok Tradisional \\
\hline Saling ketergantungan positif. & $\begin{array}{l}\text { Adanya anggota yang mendominasi atau } \\
\text { bergantung pada kelompok atau anggota lain. }\end{array}$ \\
\hline Akuntabilitas individual. & $\begin{array}{l}\text { Tugas-tugas sering diborong oleh salah seorang } \\
\text { anggota kelompok. }\end{array}$ \\
\hline Anggota kelompok heterogen. & Anggota kelompok homogeny. \\
\hline Pimpinan kelompok dipilih secara demokratis. & Pimpinan kelompok sering ditentukan oleh guru. \\
\hline $\begin{array}{l}\text { Saling membantu dan saling memberikan } \\
\text { motivasi. }\end{array}$ & Kadang yang bekerja hanya satu, dua orang. \\
\hline $\begin{array}{l}\text { Penyelesaian tugas mempertahankan hubungan } \\
\text { interpersonal. }\end{array}$ & $\begin{array}{l}\text { Penyelesaian tugas tanpa memperhatikan } \\
\text { hubungan interpersonal. }\end{array}$ \\
\hline Keterampilan sosial dibutuhkan. & Tidak membutuhkan keterampilan social. \\
\hline $\begin{array}{l}\text { Guru melakukan observasi dan intervensi } \\
\text { kelompok. }\end{array}$ & $\begin{array}{l}\text { Guru sering tidak melakukan observasi dan } \\
\text { intervensi kelompok. }\end{array}$ \\
\hline $\begin{array}{l}\text { Guru memperhatikan keefektifan proses } \\
\text { kelompok belajar. }\end{array}$ & Guru sering tidak peduli dengan keefektifan proses. \\
\hline
\end{tabular}

Sumber:Nurhadi, dkk. 2003:62 
menambah kemampuan berpikir sendiri. Untuk selanjutnya siswa dapat mengembangkan kemampuan ide atau gagasan. Kemudian membantu anak untuk merespon orang lain yang ada di sekitar mereka dan memberdayakan siswa untuk lebih bertanggung jawab dalam belajar. Siswa mampu meningkatkan prestasi akademik sekaligus kemampuan sosial. Dapat meningkatkan kemampuan siswa dalam mengembangkan ide dan pemahamannya sendiri, saat menerima umpan balik. Meningkatkan kemampuan siswa menggunakan informasi, dan kemampuan belajar abstrak menjadi nyata. Dapat meningkatkan motivasi dan memberikan rangsangan untuk berpikir.

Kelemahan pembelajaran kooperatif yaitu, luasnya pembelajaran sehingga apabila keluasan tersebut tidak dilaksanakan dengan optimal maka tujuan dari pembelajaran tersebut tidak akan tercapai. Penilaian kelompok dapat membutakan penilaian secara individu, apabila guru tidak jeli dalam pelaksanaannya. Pada proses pengembangan kesadaran berkelompok diperlukan waktu yang panjang.

\section{Pembelajaran Kooperatif Tipe STAD}

Sebuah tim dalam STAD merupakan sebuah kelompok terdiri dari empat atau lima siswa yang mewakili heterogenitas kelas ditinjau dari kinerja, suku dan jenis kelamin (Mohamad, 2005). Menurut Mohamad (2005) STAD terdiri dari lima komponen utama yaitu: presentasi kelas, kerja tim, kuis, skor perbaikan individu dan penghargaan tim.

Berikut uraian secara rinci kelebihan model pembelajaran tipe STAD: (1) Setiap siswa memiliki kesempatan untuk memberikan kontribusi yang substansial kepada kelompok dan posisi anggota kelompok adalah setara (Slavin, 2005). (2) Menggalakkan interaksi secara aktif dan positif dan kerjasama anggota kelompok menjadi lebih baik (Slavin, 2005) dan (Ahmadi, 2011). (3) Membantu siswa untuk memperoleh hubungan pertemanan lintas rasial yang lebih banyak (Slavin, 2005). (4) Melatih siswa dalam mengembangkan aspek kecakapan sosial di samping kecakapan kognitif dan peran guru juga menjadi lebih aktif dan lebih terfokus sebagai fasilitator, mediator, motivator dan evaluator (Isjoni, 2010).

Selain berbagai kelebihan di atas, model STAD ini juga memiliki kelemahan. Semua model pembelajaran memang diciptakan untuk memberi manfaat yang baik atau positif pada pembelajaran, tidak terkecuali dengan model STAD ini. Namun, terkadang pada sudut pandang tertentu, langkah-langkah model tersebut tidak menutup kemungkinan terbukanya sebuah kelemahan, seperti yang dipaparkan berikut: (1) Berdasarkan karakteristik STAD jika dibandingkan dengan pembelajaran konvensional (yang hanya penyajian materi dari guru), pembelajaran menggunakan model ini membutuhkan waktu yang relatif lama, dengan memperhatikan tiga langkah STAD yang menguras waktu seperti penyajian materi dari guru, kerja kelompok dan tes individual atau kuis. (2) Model ini memerlukan kemampuan khusus dari guru. Guru berperan sebagai fasilitator, mediator, motivator dan evaluator (Isjoni, 2010). Berdasarkan asumsi tidak semua guru mampu menjadi fasilitator, mediator, motivator dan evaluator dengan baik.

Berikut dijelaskan sintaks dari pembelajaran kooperatif tipe STAD yang terdiri atas 6 fase (Trianto, 2007), yaitu:

Fase ke-1: menyampaikan semua tujuan pembelajaran yang ingin dicapai dan memotivasi siswa untuk aktif belajar.

Fase ke-2: menyajikan materi ajar kepada siswa dengan jalan mendemonstrasikan atau melalui bahan bacaan.

Fase ke-3: menjelaskan kepada siswa bagaimana cara membentuk kelompok belajar. 
Fase ke-4: membimbing setiap kelompok belajar untuk belajar dan bekerja.

Fase ke-5: mengevaluasi hasil belajar dan kerja masing-masing kelompok.

Fase ke-6: Guru memberikan penghargaan kepada para siswa baik sebagai individu maupun kelompok, karena usaha yang telah mereka lakukan maupun karena hasil yang telah mereka capai.

\section{Pembelajaran Kooperatif Tipe NHT}

Pembelajaran kooperatif tipe NHT menurut Isjoni (2010) adalah suatu model pembelajaran dimana siswa dalam kelompok kecil terdiri 4-6 orang, siswa belajar dan bekerja secara kolaboratif dengan struktur kelompok yang heterogen. Tujuan pembelajaran kooperatif adalah untuk meningkatkan partisipasi siswa dan mempersiapkan siswa agar memiliki sifat kepemimpinan. Pembelajaran kooperatif tipe Numbered Head Together (NHT) merupakan salah satu teknik pembelajaran kooperatif, dimana melibatkan lebih banyak siswa dalam menelaah materi yang tercakup dalam suatu pelajaran, dan mengecek pemahaman mereka terhadap isi pelajaran tersebut. Menurut Trianto (2007) sintaks NHT terbagi menjadi empat fase berikut:

Fase Ke-1: Penomoran.

Fase ke-2: Mengajukan pertanyaan.

Fase ke-3: Berpikir bersama.

Fase ke-4: Menjawab.

Berikut dijelaskan keunggulan atau kelebihan dan kelemahan atau kekurangan model pembelajaran kooperatif tipe NHT menurut Arends (2008).

Keunggulan atau kelebihan model pembelajaran kooperatif tipe NHT yaitu: (1) Terjadinya interaksi antara siswa melalui diskusi atau siswa secara bersama-sama dalam menyelesaikan masalah yang dihadapi. (2) Siswa pandai maupun siswa lemah sama-sama memperoleh manfaat melalui aktivitas belajar kooperatif. (3) Melalui kerjasama secara kooperatif ini, kemungkinan konstruksi pengetahuan menjadi lebih besar atau kemungkinan untuk siswa dapat sampai pada kesimpulan yang diharapkan. (4) Memberikan kesempatan pada siswa untuk menggunakan keterampilan bertanya, berdiskusi, dan mengembangkan bakat kepemimpinan.

Kelemahan atau kekurangan model pembelajaran kooperatif tipe NHT yaitu: (1) Siswa yang pandai cenderung mendominasi sehingga dapat menimbulkan sikap minder dan pasif dari siswa yang lemah. (2) Proses diskusi tidak dapat berjalan dengan lancar, jika ada siswa yang sekedar menyalin pekerjaan siswa yang pandai tanpa memiliki pemahaman yang memadai. (3) Pengelompokan siswa memerlukan pengaturan tempat duduk yang berbedabeda serta membutuhkan waktu khusus.

\section{Hasil Belajar}

Belajar adalah suatu proses usaha yang dilakukan seseorang untuk memperoleh suatu perubahan tingkah laku yang baru secara keseluruhan, sebagai hasil pengalamannya sendiri dalam interaksi dengan lingkungannya (Daryanto, 2010). Djamarah (2008) mengatakan bahwa belajar adalah serangkaian kegiatan jiwa raga untuk memperoleh suatu perubahan tingkah laku, sebagai hasil dari pengalaman individu dalam interaksi dengan lingkungannya yang menyangkut kognitif, afektif, dan psikomotor. Slameto (2010) menyatakan bahwa belajar merupakan suatu proses perubahan, yaitu perubahan tingkah laku sebagai hasil dari interaksi dengan lingkungannya dalam memenuhi kebutuhan. Dari beberapa uraian pernyataan di atas dapat disimpulkan bahwa belajar adalah serangkaian kegiatan jiwa raga untuk memperolah suatu perubahan tingkah laku yang baru secara keseluruhan, dalam memenuhi kebutuhan.

Faktor-faktor yang mempengaruhi belajar dan hasil belajar menurut Djamarah 
(2008) adalah: faktor lingkungan, instrumental, fisiologis, psikologis. Sedangkan menurut menurut Slameto (2010) faktor-faktor yang mempengaruhi hasil belajar dapat dibagi menjadi dua macam yaitu faktor yang berasal dari diri siswa (intern) yang terdiri dari: faktor jasmani, psikologi, dan faktor yang berasal dari luar diri siswa (ekstern) yaitu: Faktor keluarga, faktor sekolah, faktor masyarakat.

Selain faktor-faktor yang telah diuraikan di atas, ada faktor lain yang tidak kalah penting berpengaruhnya terhadap hasil belajar. Faktor tersebut yaitu penggunaan model pembelajaran yang tepat pada saat proses pembelajaran.

\section{METODE}

Jenis penelitian ini adalah penelitian eksperimen. Penelitian ini menggunakan desain penelitian Quasi Experimental Design. Oleh karena desain ini hampir sama bentuknya dengan pretest-postest control group design, hanya pada desain ini kelompok eksperimen maupun kelompok kontrol tidak dipilih secara random. Dalam desain ini, baik kelompok eksperimental maupun kelompok kontrol dibandingkan, kendati kelompok tersebut dipilih dan ditempatkan tanpa melalui random. Dua kelompok yang ada diberi pretest, kemudian diberikan perlakuan, dan terakhir diberikan postes.

\section{Desain penelitian}

\begin{tabular}{lccc}
\hline Kelompok & Pretes & Perlakuan & Postest \\
\hline Kelas A & $\mathrm{O}_{1}$ & $\mathrm{X}_{1}$ & $\mathrm{O}_{2}$ \\
Kelas F & $\mathrm{O}_{1}$ & $\mathrm{X}_{2}$ & $\mathrm{O}_{2}$ \\
\hline
\end{tabular}

Keterangan: $\mathrm{O}_{1}=$ Pretest

$\mathrm{X}_{1}=$ Pembelajaran dengan model STAD

$\mathrm{X}_{2}=$ Pembelajaran dengan model NHT

$\mathrm{O}_{2}=$ Postest

Subjek penelitian ini adalah siswa kelas VIII SMP Negeri 1 Getasan, dengan kelas VIII A yang diajar dengan model STAD dan Kelas VIII F dengan model NHT. Masing-masing kelas terdiri dari 32 siswa.
Teknik yang digunakan dalam pengumpulan data adalah tes, dan observasi secara langsung. Penelitian ini menggunakan teknik tes (pre-tes dan post-tes), dan observasi sebagai teknik pelengkap untuk memperkuat dan mengetahui keadaan siswa.

Pengujian instrumen terdiri dari uji validitas dan uji reliabilitas. Uji validitas dilakukan untuk menunjukkan sejauh mana skor atau nilai atau ukuran yang diperoleh benar-benar menyatakan hasil pengukuran atau pengamatan yang ingin diukur (Agung, 1990). Butir-butir soal dinyatakan valid apabila nilai dari korelasi item total >0,3 (Guilford,1954). Sedangkan uji reliabilitas merupakan indeks yang menunjukkan sejauh mana suatu alat pengukur dapat dipercaya atau dapat diandalkan (Singarimbun, 1989). Pada penelitian ini peneliti menggunakan bantuan SPSS 19 untuk menentukan validitas dan reliabilitas tiap-tiap soal yang diberikan kepada siswa, yaitu dengan teknik pengujian cronbanch alpha. Rumus untuk menghitung koefisien reliabilitas instrument dengan menggunakan cronbanch alpha adalah sebagai berikut:

$r_{a}=\left[\frac{k}{(k-1)}\right]\left[1-\frac{\sum \sigma_{b}^{2}}{\sigma_{t}^{2}}\right]$

Keterangan:

$r_{a} \quad=$ koefisien reliabilitas instrument (cronbanch alpha)

$k \quad=$ banyak butir soal atau pertanyaan

$\sum \sigma_{t}^{2}=$ total variansi butir soal atau pertanyaan

$\sigma_{t}^{2}=$ variansi butir soal atau pertanyaan

Setelah didapatkan hasil perhitungan $r_{a}$, kemudian dikonsultasikan ke Tabel $r$ product moment. Bila $r_{a}$ dihitung lebih besar dari $r_{\text {table, }}$, maka dapat dikatakan bahwa butir-butir soal tes adalah reliable. Adapun tolok ukur untuk menginterpretasikan kriteria reliabilitas instrument menurut Suharsimi Arikunto (2003) dibagi menjadi beberapa interval seperti berikut: 


$$
\begin{aligned}
& 0,80<r_{a} \text { d" } 1,00=\text { Sangat Tinggi } \\
& 0,60<r_{a}<0,8=\text { Tinggi } \\
& 0,40<r_{a}<0,6=\text { Sedang } \\
& 0,20<r_{a}<0,4=\text { Rendah } \\
& 0,00<r_{a}<0,2=\text { Sangat rendah }
\end{aligned}
$$

Sebelum instrumen digunakan dalam penelitian, terlebih dahulu dilakukan uji coba di lapangan. Hal tersebut dilakukan untuk mengetahui kesahihan dan kehandalan instrumen melalui uji validitas dan reliabilitas.

Tabel 2. Hasil Uji validitas tiap butir soal

\begin{tabular}{ccc}
\hline $\begin{array}{c}\text { Soal no } \\
\text { Ke }\end{array}$ & $\begin{array}{c}\text { Total item } \\
\text { korelasi }\end{array}$ & Keterangan \\
\hline 1 & 0,35 & Valid \\
2 & 0,36 & Valid \\
3 & 0,38 & Valid \\
4 & 0,50 & Valid \\
5 & 0,41 & Valid \\
6 & 0,33 & Valid \\
7 & 0,39 & Valid \\
8 & 0,40 & Valid \\
9 & 0,44 & Valid \\
10 & 0,49 & Valid \\
\hline
\end{tabular}

Sumber: Data primer yang diolah, 2013

Berdasarkan Tabel 2 diperoleh keterangan bahwa nilai total item korelasi untuk masingmasing butir soal adalah valid. Sehingga dapat disimpulkan bahwa semua instrumen yang diujicobakan, dapat digunakan sebagai instrumen dalam penelitian.

Tabel 3. Koefisien Reliabilitas

\begin{tabular}{ccc}
\hline $\begin{array}{c}\text { Cronch's } \\
\text { Alpha }\end{array}$ & Total item korelasi & Keterangan \\
\hline 0.685 & $0,6<\mathrm{r}_{\mathrm{a}}<0,8$ & Tinggi \\
\hline
\end{tabular}

Sumber: Data primer yang diolah, 2013

Dari Tabel 3 dapat disimpulkan bahwa nilai koefisien reliabilitas untuk instrument soal adalah reliabel, dengan nilai reliabilitas tinggi (Suharsimi Arikunto, 2003). Oleh karena hal tersebut maka instrumen dapat digunakan dalam penelitian.
Analisis data merupakan langkah yang sangat penting dalam penelitian, setelah data terkumpul lengkap, data harus dianalisis baik menggunakan analisis kualitatif maupun kuantitatif. Proses pengorganisasian dan mengurutkan data ke dalam pola, kategori dan satuan dasar sehingga dapat ditemukan tema dan dapat dirumuskan hipotesis seperti sasaran data (Iqbal, 2002). Data yang telah terkumpul diolah dan dianalisis menggunakan uji t (dua arah). Hal tersebut dilakukan karena dengan menggunakan uji t dapat diperkirakan interval ratarata data yang diperoleh, menguji hipotesis tentang rata-rata suatu sampel, dan menunjukkan batas penerimaan suatu hipotesis. Selain itu dengan penggunaan uji-t peneliti dapat menguji suatu pernyataan apakah sudah layak untuk dipercaya atau belum.

Uji homogenitas digunakan untuk menen-tukan kehomogenan data yang terdiri dari dua kelas atau untuk mengetahui keadaan varians kedua kelompok sama atau berbeda. Uji statistik dengan menguji uji-F sebagai berikut:

$$
F=\frac{s_{b}^{2}}{s_{k}^{2}}
$$

Keterangan:

$$
s_{b}^{2}=\text { varians besar, } s_{k}^{2}=\text { varians kecil. }
$$

Harga $\mathrm{F}$ hitung yang diperoleh dari perhitungan ini kemudian dibandingkan dengan harga $\mathrm{F}$ tabel pada taraf kepercayaan tertentu. Taraf kepercayaan yang digunakan yaitu $\alpha=0.05$, derajat kebebasan masing-masing $\mathrm{dk}_{\mathrm{b}}=\left(\mathrm{n}_{\mathrm{b}}-1\right)$ dan $\mathrm{dk}_{\mathrm{k}}=\left(\mathrm{n}_{\mathrm{k}}-1\right)$, dengan kriteria yang digunakan untuk menentukan apakah variansi homogen atau tidak adalah:

a. Bila $F$ hitung $<F$ tabel maka variansi homogen, artinya $=s_{b}^{2}=s_{k}^{2}$

b. Bila $\mathrm{F}$ hitung $>\mathrm{F}$ tabel maka variansi tidak homogen, artinya $s_{b}^{2}=s_{k}^{2}$.

(Panggabean, 2001). 


\section{Uji Normalitas}

Uji normalitas digunakan untuk mengetahui apakah data yang diperoleh berdistribusi normal atau tidak berdistribusi normal. Jika data berdistribusi normal, maka dilakukan pengujian parametrik. Namun jika data tidak berdistribusi normal, maka dilakukan pengujian non-para-metrik dengan model Kolmogorov Smirnov.

\section{Gain atau Peningkatan Skor}

Gain adalah selisih antara nilai postes dan pretes, melalui gain ditunjukkan peningkatan pemahaman atau penguasaan konsep siswa, setelah pembelajaran dilakukan oleh guru. Kelebihan penggunaan model dalam meningkatkan keterampilan berpikir kritis, ditinjau berdasarkan perbandingan nilai gain yang dinormalisasi (N-gain) antara kelompok eksperimen dan kelompok kontrol. Gain yang dinormalisasi ( $\mathrm{N}$-gain) dapat dihitung dengan persamaan sebagai berikut:

$$
G=T_{2}-T_{1}:<g>=\frac{T_{2}-T_{1}}{I_{s}-T_{1}}
$$

Keterangan: $\mathrm{G}=$ gain

$$
\begin{aligned}
\langle\mathrm{g}\rangle & =\text { gain normal } \\
\mathrm{T}_{1} & =\text { skor pretes } \\
\mathrm{T}_{2} & =\text { skor postes } \\
\mathrm{I}_{\mathrm{s}} & =\text { skor ideal. }
\end{aligned}
$$

Perbedaan antara skor pretes dan skor postes ini diasumsikan sebagai efek dari perlakuan (Arikunto, 1998).

\section{Uji Hipotesis}

Uji hipotesis penqlitian dilakukan untuk mengetahui hipotesis yang diajukan diterima atau ditolak. Digunakan perhitungan statistik dengan menggunakan uji perbedaan dua ratarata (Uji-t) dua sampel yang saling independen apabila data kedua kelas berdistribusi normal dan jika kedua kelas tidak semua berdistribusi normal, maka pengujian dilakukan dengan menggunakan uji non-parametrik dua sampel yang saling independen (Uji Mann Whitney).
Hipotesis nol $\left(\mathrm{H}_{0}\right)$ dan Hipotesis Alternatif $\left(\mathrm{H}_{1}\right)$. Hipotesis nol $\left(\mathrm{H}_{0}\right)$ adalah suatu pernyataan mengenai nilai parameter populasi. Sedangkan hipotesis alternatif $\left(\mathrm{H}_{1}\right)$ adalah suatu pernyataan yang diterima jika data sampel memberikan cukup bukti bahwa hipotesis nol adalah ditolak. Hipotesis pada penelitian ini adalah sebagai berikut:

$\mathrm{H}_{\mathrm{o}}: \mu_{1}=\mu_{2}$ Tidak ada perbedaan hasil belajar siswa pada matapelajaran matematika yang diajar menggunakan model pembelajaran kooperatif tipe STAD di kelas VIII A, dan model pembelajaran kooperatif tipe NHT di kelas VIII F, di SMP Negeri 1 Getasan.

$\mathrm{H}_{1}: \mu_{1} \neq \mu_{2} \quad$ Ada perbedaan hasil belajar siswa pada matapelajaran matematika yang diajar menggunakan model pembelajaran kooperatif tipe STAD di kelas VIII A, dan model pembelajaran kooperatif tipe NHT di kelas VIII F, di SMP Negeri 1 Getasan.

\section{HASIL DAN PEMBAHASAN}

Berdasarkan hasil perhitungan terhadap data yang diperoleh, didapatkan nilai untuk hasil uji homogenitas untuk kelas STAD dan NHT yang ditunjukkan pada Tabel 4.

Tabel 4. Hasil Uji Homogenitas Variansi Skor Pretes dan Postes Kelas STAD dan NHT

\begin{tabular}{ccccc}
\hline & $\begin{array}{c}\text { Levene } \\
\text { Statistik }\end{array}$ & Df1 & Df2 & Signifikansi \\
\hline $\begin{array}{c}\text { Pretest kedua } \\
\text { kelas } \\
\begin{array}{c}\text { Postest kedua } \\
\text { kelas }\end{array}\end{array}$ & 0.880 & 1 & 62 & 0.352 \\
\hline
\end{tabular}

Sumber: Data primer yang diolah, 2013

Berdasarkan Tabel 4, nampak bahwa skor pretes dan postes kelas STAD dan NHT memiliki nilai signifikansi yang lebih besar dari $\alpha=0.05$. Hal ini menunjukkan bahwa $\mathrm{H}_{0}$ diterima, sehingga dapat dikatakan bahwa data 
skor pretes dan postes kedua kelas berasal dari varians yang homogen. Untuk langkah selanjutnya akan dilakukan uji normalitas. Hal tersebut dilakukan untuk mengetahui apakah masing-masing kelas memiliki distribusi normal atau tidak. Berikut ditunjukkan pada Tabel 5 secara ringkas, hasil uji normalitas kelas STAD dan NHT.

Tabel 5. Hasil Uji Normalitas Pretes dan Postes Kelas STAD dan NHT

\begin{tabular}{lcccc}
\hline & \multicolumn{2}{c}{ Pretest } & \multicolumn{2}{c}{ Postes } \\
\hline & Kelas & Kelas & Kelas & Kelas \\
& STAD & NHT & STAD & NHT \\
\hline $\mathrm{N}$ & 32 & 32 & 32 & 32 \\
Kolmogorov - & 0.870 & 1.165 & 1.129 & 1.252 \\
Smirnov & 0.435 & 0.132 & 0.156 & 0.087 \\
Sig. (2 -tailed) & 0.3013 & & \\
\hline Sumber: Data primer yang diolah, 2013
\end{tabular}

Dari Tabel 5 nampak bahwa skor pretes dan postes hasil belajar siswa kelas STAD dan NHT, memiliki nilai signifikansi yang lebih besar dari $\alpha=0.05$ sehingga $\mathrm{H}_{0}$ dapat diterima. Hal ini menunjukkan bahwa data skor pretes dan postes hasil belajar siswa kelas STAD dan NHT berdistribusi normal.

Selanjutnya untuk menguji nilai tes awal antara kelas STAD dan NHT apakah memiliki kemampuan awal yang sama atau tidak, maka dilakukan uji kesamaan rataan pretes dengan uji-t, yaitu menggunakan Compare Mean Paired Samples Test dengan taraf signifikansi $\alpha=0.05$. Adapun hasil pretes kelas STAD dan NHT, ditunjukkan pada Tabel 6 berikut.

Tabel 6. Hasil Uji Beda Postes STAD dan NHT

\begin{tabular}{ccccc}
\hline \multicolumn{2}{c}{ STAD } & \multicolumn{2}{c}{ NHT } & \multirow{2}{*}{ Sig. (2- } \\
\cline { 1 - 4 } Rerata & $\begin{array}{c}\text { Standar } \\
\text { Deviasi }\end{array}$ & Rerata & $\begin{array}{c}\text { Standar } \\
\text { Deviasi }\end{array}$ & $\begin{array}{c}\text { tailed) } \\
\end{array}$ \\
\cline { 1 - 4 } 88.13 & 10.298 & 73.13 & 9.980 & 0.000 \\
\hline
\end{tabular}

Sumber: Data primer yang diolah, 2013

Dari Tabel 6 tampak bahwa hasil postes kedua kelas cukup berbeda jauh. Perbedaan ini signifikan antara kelas STAD dan NHT. Hasil uji beda rataan yang diperoleh memiliki nilai signifikansi sebesar 0.000, hal ini berarti lebih kecil dari nilai $\alpha=0.05$. Jadi dapat disimpulkan, bahwa kedua kelas memiliki kemampuan yang berbeda, setelah diberi perlakuan yang berbeda pula. Sebelum melakukan uji hipotesis terhadap kedua kelas, maka terlebih dahulu dilakukan pencapaian skor (gain), baik pada kelas STAD maupun NHT. Rangkuman rataan gain dari hasil belajar matematika masingmasing kelas dapat dilihat pada Tabel 7.

Tabel 7. Rataan Gain Hasil Belajar Matematika

\begin{tabular}{cclc}
\hline Kelas & Mean & $\begin{array}{l}\text { Standar } \\
\text { Deviasi }\end{array}$ & $\mathrm{N}$ \\
\hline STAD & 25.31 & 29.510 & 32 \\
NHT & 11.88 & 12.556 & 32 \\
\hline
\end{tabular}

Sumber: Data primer yang diolah, 2013

Dari Tabel 7 dapat diambil kesimpulan bahwa rataan gain peningkatan hasil belajar dengan model pembelajaran STAD sebesar 25.31, terlihat lebih tinggi dibandingkan dengan pembelajaran model NHT sebesar 11.88. Adapun hasil uji-t dengan menggunakan Paired Sampel T-test dengan bantuan software SPSS, dapat dilihat pada Tabel 8.

Berdasarkan Tabel 8 tersebut, dapat diuji apakah ada perbedaan rata-rata skor pada kelas STAD dan NHT dengan taraf signifikansi kepercayaan sebesar 95 persen. Langkah awal dilakukan dengan menyusun hipotesis yang dirumuskan untuk pengujian, menggunakan perbedaan mean atau rata-rata hitung, seperti berikut:

$\mathrm{H}_{0}: \mu_{1}=\mu_{2}$ Tidak ada perbedaan hasil belajar siswa pada matapelajaran matematika yang diajar menggunakan model pembelajaran kooperatif tipe STAD di kelas VIIIA, dan model pembelajaran kooperatif tipe NHT di kelas VIII F, di SMP Negeri 1 Getasan.

$\mathrm{H}_{1}: \mu_{1} \neq \mu_{2} \quad$ Ada perbedaan hasil belajar siswa pada matapelajaran matematika yang diajar meng- 
gunakan model pembelajaran kooperatif tipe STAD di kelas VIII A, dan model pembelajaran kooperatif tipe NHT di kelas VIII F, di SMP Negeri 1 Getasan.

Keputusan diambil dengan melakukan pembandingan dari nilai $t_{\text {hitung }}$ dengan $t_{\text {tabel }}$. memberikan hasil yang lebih baik jika dibandingkan dengan pembelajaran model NHT. Hal tersebut juga ditunjukkan dari hasil perhitungan yang diperoleh, yaitu terdapat perbedaan signifikan antara kedua kelas. Kelas STAD memperoleh gain sebesar 25.31, sedangkan kelas NHT dengan gain sebesar 11.88.

Tabel 8. Uji-t Perbedaan Rata-rata Gain Kelas STAD dan NHT

\begin{tabular}{|c|c|c|c|c|c|c|c|c|c|c|}
\hline & \multicolumn{2}{|c|}{$\begin{array}{l}\text { Levene's Test } \\
\text { for Equality } \\
\text { of Variances }\end{array}$} & \multicolumn{7}{|c|}{ t-test for Equality of Means } \\
\hline & & \multirow[t]{2}{*}{$\mathrm{F}$} & \multirow[t]{2}{*}{ Sig. } & \multirow[t]{2}{*}{$\mathrm{T}$} & \multirow[t]{2}{*}{ Df } & \multirow[t]{2}{*}{$\begin{array}{c}\text { Sig. } \\
\text { (2-tailed) }\end{array}$} & \multirow[t]{2}{*}{$\begin{array}{c}\text { Mean } \\
\text { Difference }\end{array}$} & \multirow[t]{2}{*}{$\begin{array}{l}\text { Std. Error } \\
\text { Difference }\end{array}$} & \multicolumn{2}{|c|}{$\begin{array}{l}95 \% \text { Confidence } \\
\text { Interval of the } \\
\text { Difference }\end{array}$} \\
\hline & & & & & & & & & Lower & Upper \\
\hline \multirow{2}{*}{ a } & $\begin{array}{c}\text { Equal variances } \\
\text { assumed }\end{array}$ & 24.75 & .000 & 2.370 & 62 & .021 & 1.344 & .567 & .210 & 2.477 \\
\hline & $\begin{array}{l}\text { Equal variances } \\
\text { not assumed }\end{array}$ & & & 2.370 & 41.87 & .022 & 1.344 & .567 & .200 & 2.488 \\
\hline
\end{tabular}

Sumber: Data primer yang diolah, 2013

Berdasarkan hasil perhitungan yang diperoleh tampak bahwa nilai $\mathrm{t}_{\text {hitung }}=2,370$, dan $\mathrm{t}_{\text {tabel }}$ dapat dicari pada tabel distribusi $t$ yaitu pada taraf kepercayaan 95 persen $(\alpha=5 \%)$. Oleh karena uji- $t$ bersifat dua arah, maka nilai $\alpha$ yang digunakan pada tabel $\mathrm{t}$ adalah $\alpha / 2=0,05 / 2=$ 0,025 . Untuk derajat bebas $(d f)=\left(\mathrm{n}_{1}+\mathrm{n}_{2}\right)-2$ $=(32+32)-2=62$, sehingga diperoleh nilai $\mathrm{t}_{\text {tabel }}=1,998$. Karena $\mathrm{t}_{\text {hitung }}>\mathrm{t}_{\text {tabel }}$, maka $\mathrm{H}_{0}$ ditolak. Berdasarkan uji-t maka dapat disimpulkan bahwa terdapat perbedaan hasil belajar siswa kelas VIII yang diajar dengan menggunakan Model pembelajaran STAD dan NHT pada mata pelajaran matematika di SMP Negeri 1 Getasan.

Perolehan hasil tes secara keseluruhan dengan jelas menunjukkan bahwa hasil skor rata-rata pretes kelas STAD sebesar 62.19 dan skor rata-rata postes kelas STAD sebesar 88.13. Sedangkan untuk skor rata-rata pretes kelas NHT sebesar 61.22 dan skor rata-rata postes kelas NHT sebesar 73.13. Oleh karena adanya perbedaan yang signifikan, ini menunjukkan bahwa pembelajaran model STAD dapat

\section{KESIMPULAN}

Dari hasil penelitian yang telah dilakukan dapat disimpulkan bahwa, terdapat perbedaan hasil belajar yang signifikan antara Model Pembelajaran Kooperatif Tipe STAD dengan Model Pembelajaran Kooperatif Tipe NHT. Hal tersebut dapat dilihat dari peningkatan hasil belajar siswa, baik yang diajar menggunakan Model Pembelajaran Kooperatif Tipe STAD maupun Tipe NHT. Melalui rataan peningkatan hasil belajar, dapat ditunjukkan peningkatan pemahaman atau penguasaan konsep oleh siswa setelah proses pembelajaran dilakukan. Rataan peningkatan hasil belajar siswa untuk kelas STAD adalah sebesar 25.31, yang diperoleh dari rataan nilai postes sebesar 88.13 dikurangkan dengan rataan pretes sebesar 62.19. Sedangkan rataan peningkatan hasil belajar siswa untuk kelas NHT adalah sebesar 11.88, dengan rataan nilai psotes sebesar 71.13 dan rataan nilai pretes sebesar 61.22. Perbedaan hasil belajar ini dapat terjadi karena proses pembelajaran di kelas STAD lebih efektif, dibandingkan dengan proses pembelajaran yang terjadi di kelas NHT. 
Keefektifan tersebut terlihat pada saat proses pembelajaran, dimana siswa kelas STAD lebih aktif dalam merespon pengajaran yang dilakukan pengajar. Lain halnya dengan yang terjadi di kelas NHT, dimana siswa kurang aktif dalam merespon proses pembelajaran yang dilakukan oleh pengajar. Kurang aktifnya siswa dalam merespon proses pembelajaran tersebut dapat dimungkinkan terjadi, karena adanya pengaruh faktor eksternal seperti pengaruh faktor lingkungan dan faktor budaya.

\section{SARAN}

Berdasarkan hasil penelitian yang telah dilakukan di SMP Negeri 1 Getasan, maka dapat disampaikan saran berikut:

1. Bagi siswa, agar diperoleh hasil belajar yang maksimal sebaiknya dalam proses penyampaian pembelajaran guru tidak hanya menggunakan model pembelajaran konvensional. Tetapi juga dapat menggunakan model pembelajaran Kooperatif tipe STAD dan NHT.

2. Bagi guru, dalam penggunaan model pembelajaran Kooperatif tipe STAD dan NHT, hendaknya persiapan waktu untuk proses pembelajaran lebih matang. Sehingga pelaksanaan proses pembelajaran dapat terlaksana secara maksimal. Selain itu diharapkan guru lebih mengoptimalkan peran dan fungsinya sebagai motivator, fasilitator dan evaluator dalam proses pembelajaran.

Bagi sekolah, berdasarkan keuntungan dan kelemahan yang dimiliki oleh kedua model pembelajaran, diharapkan sekolah dapat lebih tepat dalam memilih dan menerapkan model pembelajaran yang digunakan. Sehingga dalam proses pelaksanaan pembelajaran di kelas dapat diperoleh hasil belajar yang optimal, baik untuk mata pelajaran matematika maupun mata pelajaran yang lain

\section{DAFTAR PUSTAKA}

Agung, 1990. Metode Penelitian Sosial Pengertian dan Pemakaian Praktis. Jakarta.

Arends, R.I. 2008. Learning To Teach (Belajar Untuk Mengajar). Yogyakarta: Pustaka Belajar.

Dekdikbud. 2006. Kurikulum 2006 Kurikulum Tingkat Satuan Pendidikan (KTSP). Jakarta: Dekdikbud.

Depdiknas. 2003. Kurikulum 2004, Standar Kompetensi, Mata Pelajaran Kelas V Sekolah Dasar (SD) dan Madrasah Ibtidaiyah. Jakarta.

Dimyanti dan Mudjiono. 2002. Belajar dan Perkembangan. Jakarta: Rineka Cipta.

Djamarah, Syaiful Bahri. 2008. Psikologi Belajar. Jakarta: PT. Rineka Cipta.

Guilford, J. P. 1954. Psychometric Methods. Tokyo: Kogakusha Co. Ltd., McGrawHill Book Company, Inc.

Hamzah, B. Uno. 2007. Pembelajaran Menciptakan Proses Belajar Mengajar yang Kreatif dan Efektif, Jakarta: Bumi Aksara.

Iqbal, Hasan. 2002. Pokok-Pokok Materi Metodologi Penelitian dan Aplikasinya. Jakarta.

Isjoni. 2010. Cooperative Learning. Bandung. CV Alfabeta.

Mohamad, Nur. 2005. Pembelajaran Kooperatif. Dirjen Dikti Depdiknas.

Nurhadi, dkk. 2003. Pembelajaran Kontekstual dan Penerapannya dalam KBK. Malang: Universitas Negeri Malang.

Pandoyo.1997 Matematika Kelas VI. Jakarta: Departemen Pendidikan dan Kebudayaan.

Sanjaya. 2008. Perencanan dan desain sistem pembelajaran. Jakarta: PT. Fajar Interpratama. 
Singarimbun, Masri dkk. 1989. Metode Penelitian survei, Cetakan Ke-18, Februari 2006(Edisi Revisi). Jakata: LP3ES.

Slameto. 2003. Belajar dan Faktor-Faktor yang Mempengaruhinya. Jakarta: Rineka Cipta. 2010. Belajar dan Faktor-Faktor yang Mempengaruhinya. Jakarta: PT Rineka Cipta.
Tim PPPG Matematika. 2004. PPPG Matematika, Model-Model Pembelajaran Matematika. Yogyakarta: PPPG Matematika.

Trianto. 2007. Model-model Pembelajaran Inovatif Berorientasi Konstruktivistik. Jakarta: Prestasi Pustaka. 